\title{
Analysis the Performance of Chemical and Physical Additives to Reduce Shrinkage of Drinking Water Treatment Sludge (DWTS)
}

\author{
Himahansi H. Galkanda and Rangika U. Halwatura
}

\begin{abstract}
Water is one of the basic human needs and the country has the main responsibility to confirm their citizens' provision to safe water. Most of the countries in the world supply treated water to the country through water treatment plants. In drinking water treatment plants, solid sludge is generated at the end of the water treatment process as a waste product which is now becoming a global problem. In previous studies, shrinkage was identified as the major problem of drinking water treatment sludge (DWTS), accrued when use it as a raw material. This study was conducted to analyze the performance of both chemical and physical additives, to identify the possible additive to overcome the shrinkage of DWTS. In the study eight mixtures were prepared by adding Styrene Acrylic Binder as the chemical additive and sand and sugarcane fiber as physical additives separately and together and volumetric shrinkage of each mix was measured weekly. According to the results of this study it was concluded as, shrinkage of DWTS can be reduced by adding physical additives. Physical additives perform more effectively than chemical additives in the reduction of shrinkage of DWTS. Further studies are required to find the optimum mixing ratios of physical additives to optimize the performances.
\end{abstract}

Index Terms - Chemical additives, drinking water treatment sludge (DWTS), physical additives, shrinkage.

\section{INTRODUCTION}

Provision to safe water is an essential requirement of humans. The country has the main responsibility to secure the residents ability to provision to safe water; safe water is an essential prerequisite for better health and socio economic development of a country [1]. Most of the countries in the world suffer from lack of safe water. Therefore most of the countries in the world raw water is treated through water treatment plants to secure public health [2]. Drinking water treatment plants process consist with coagulation, flocculation, sedimentation, filtration and disinfection. At the end of the process a large quantities of solid sludge is generated, which is categorized under non-hazardous industrial waste. Due to the generation in large quantities solid sludge from drinking water treatment plant is now

Manuscript received November 12, 2019; revised February 21, 2020. This work was supported in part by the NSF (National Science Foundation of Sri Lanka) under Grant RG/2017/EA \& ICT/02.

H. H. Galkanda was with University of Ruhuna, Sri Lanka. She is now with the Department of Civil Engineering, Faculty of Engineering, University of Moratuwa, Sri Lanka (e-mail: himahansi.galkanda@gmail.com).

R. U. Halwatura is with the Department of Civil Engineering, Faculty of Engineering, University of Moratuwa, Sri Lanka (e-mail: rangikauh@gmail.com). becoming a global problem [2], [3].

Sri Lanka has a better record in the water supply sector in terms of population coverage with improved water supply, compared to the other countries in the region, the challenges remain to be maintenance of the services to the current users and extension of services to the un-served population which is estimated over 3 million at present [4]. National Water Supply and Drainage Board (NWSDB) has the responsibility in water supply in Sri Lanka. The total drinking water production by NWSDB of Sri Lanka is estimated as 80 million $\mathrm{m}^{3}$ per month [4]. Considerable amount of wastewater is produced in water treatment plants due to backwashing of rapid sand filters and release of accumulated sludge in sedimentation tanks. Different water treatment plants in Sri Lanka has different sludge treatment and removal processes. According to the process, generated sludge in each plant is different to each other in moisture content [5], [6]. Biyagama water treatment plant is one of the water treatment plants where sludge treatment plant is available.

Biyagama water treatment plant production is projected as around $180,000 \mathrm{~m}^{3}$ per day, which cover around 1,000,000 populations' water requirement. Biyagama, Kelaniya, Mahara, Wattala, Jaela and Dompe Divisional Secretariats are the areas covered by Biyagama water treatment plant. Raw water is extracted from Kelani River and after removing course and fine particles, pump to the treatment plant. Biyagama water treatment plant is consist with a mixing chamber, Flocculation tank, Lamella clarifiers, sand filters, clear water and contact tank [5] as shown in Fig. 1. Alum $\left(\mathrm{Al}_{2} \mathrm{SO}_{4}\right)$, lime $\left(\mathrm{Ca}[\mathrm{OH}]_{2}\right)$ and chlorine $\left(\mathrm{Cl}_{2}\right)$ are the chemicals added in the treatment process.

Biyagama water treatment plant is consist with a sludge treatment plant to receive the residues of water treatment, recover the settled water and remove drinking water treatment sludge (DWTS) in solid form. Sludge treatment plant is consisting with wash water recovery tank, sludge balancing tank, sludge thickener tank, thickened sludge tank and sludge decanter as shown in Fig. 1. The solid sludge production of Biyagama water treatment plant is estimated at $10 \mathrm{~m}^{3}$ per day.

DWTS is classified under industrial waste and it is a nontoxic waste product when consider the chemical composition. Direct discharge of DWTS into water bodies and land is resulted in the risk of damage and disturbance of natural ecosystems. Discharge of DWTS in to water bodies in high quantities adversely affects on water quality and aquatic biota [6], [7]. Direct discharge of DWTS is prohibited by Sri 
Lankan legislations; as it is classified under industrial waste and due to the high quantity [3], [8], [9].

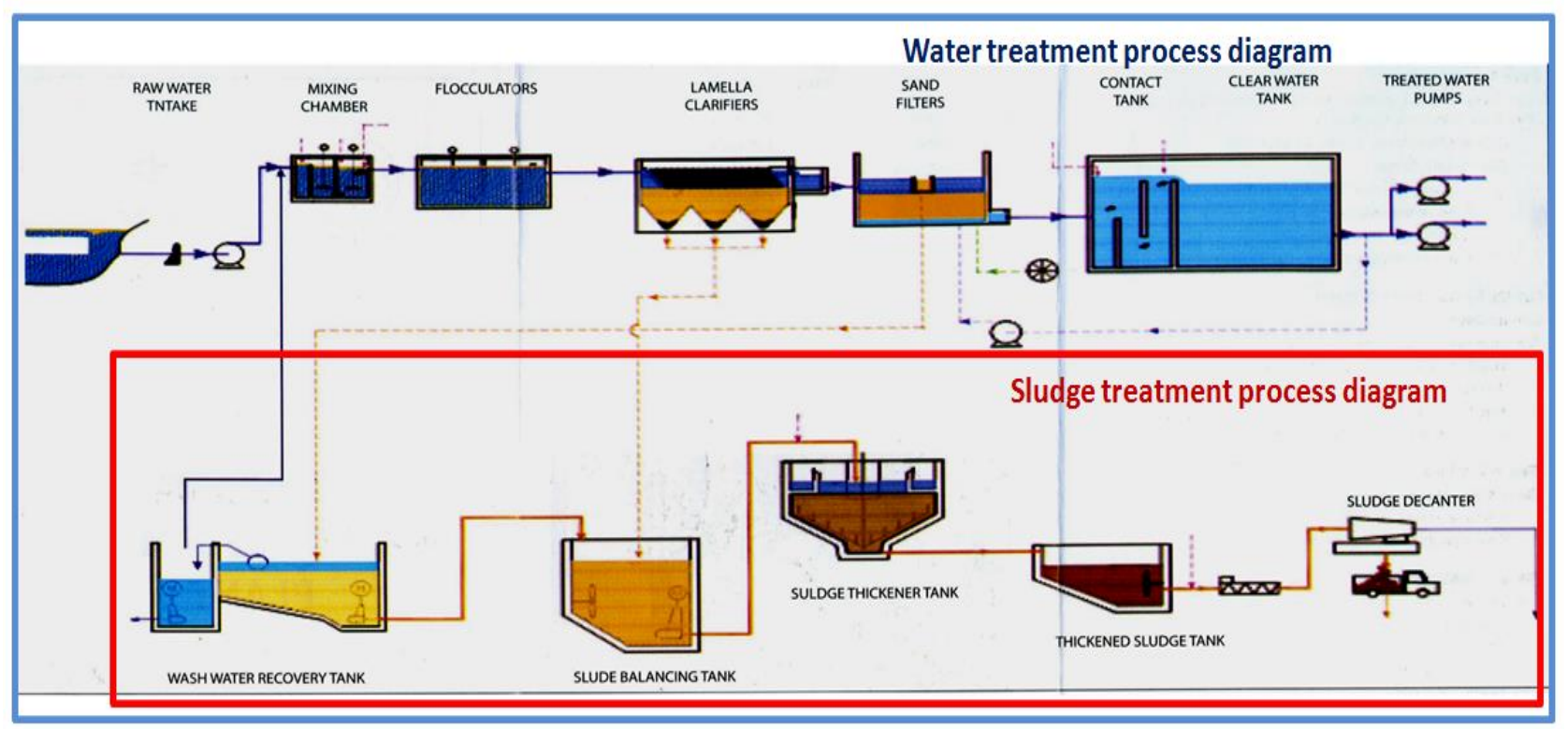

Fig. 1. Process diagram of Biyagama water treatment plant (Source - NWSDB Sri Lanka).

Therefore the problem occurred to find a sustainable solution for DWTS as there is no available sustainable standard treatment or reuse or recycle process. DWTS management is becoming a major problem now in Sri Lanka due to increasing demand for treated water [10], [11]. Conversion of the DWTS into a useful product or use as a raw material in a production process is a sustainable solution for the increasing production of DWTS [2], [3]. To use in a production process intrinsic properties of DWTS should be identified.

It was identified that the intrinsic properties of DWTS is unique for the sludge generate in each treatment plant. The nature of DWTS depends on suspended solids of raw water, coagulant type and chemicals that are used in the treatment process [1]. In water treatment plants the amount and the concentration of wastewater produced will depend on the raw water quality which may differ seasonally and regionally [12] This results DWTS with different variations of intrinsic properties.

According to the literature, studies were conducted to study the possibility of DWTS use as a raw material in the production industry. Bricks, roof tiles, lightweight aggregates, cement, concrete and geopolymers were the products that experimented to incorporate DWTS with raw materials [2], [13]-[15]. At the end of each study it was concluded as incorporating of DWTS with products is not totally success and the shrinkage of DWTS was identified as the major issue [16].

Shrinkage is one of the basic properties of DWTS which create negative impact when used as a raw material in production process. Shrinkage can be measured as volumetric shrinkage and observational shrinkage [16]. Observational shrinkage is considered as the cracks observed after drying and the volumetric shrinkage is considered as the volume reduction after drying. Historical evidence shows that natural fibers, binders and additives were used to avoid shrinkage of clay based productions and applications [17]-[19]. As the DWTS is categorized under clay; according to the USCS soil classification, shrinkage can be overcome through historical practices before used as a raw material [2], [16].

As the shrinkage was identified as the major problem of DWTS which effects negatively when use as a raw material; this study was conducted to analyze the performance of chemical and physical additives on DWTS to reduce shrinkage. So the object of this study is to analyze the shrinkage performances of DWTS when mix with chemical and physical additives to identify the potential ability of chemical and physical additives to reduce shrinkage of DWTS to use effectively in production processes.

\section{METHODOLOGY}

\section{A. Material Selection}

DWTS from Biyagama water treatment plant was selected for the study. As the initial step of the study chemical and physical properties of DWTS were tested. XRF analysis was conducted to determine the chemical composition of the DWTS [20]. Moisture content, particle size distribution and volumetric shrinkage of DWTS were initially tested. Moisture content was measured in weight basis using oven dry method and wet sieve analysis was conducted to analyze the particle size distribution in DWTS [21].

One chemical additive and two physical additives (see Table I) ware selected to measure the volumetric shrinkage after mix with DWTS. Styrene acrylic binder was selected as the chemical additive as it is one of the commonly used acrylic binder in production industry [22]. Sand is selected as a physical additive as sand is commonly utilized material in the construction industry. As a fiber, sugarcane fiber was selected. Sugarcane fiber is generated as an waste product in sugar manufacturing industry [23].

\section{B. Mix Design}

Eight different mixtures (see Table II) were prepared by 
mixing selected additives with DWTS in a mechanical mixer. After prepared the mixtures volumetric shrinkage test was conducted.

TABLE I: CHEMICAL AND PHYSICAL ADDITIVES

\begin{tabular}{|c|c|c|c|c|}
\hline \multicolumn{5}{|c|}{ Additives } \\
\hline \multicolumn{4}{|c|}{ Physical } & Chemical \\
\hline Sand & & \multicolumn{2}{|c|}{ Fiber } & $\begin{array}{c}\text { Styrene Acrylic } \\
\text { Binder }\end{array}$ \\
\hline \multicolumn{4}{|c|}{$\begin{array}{l}\text { Sugarcane fiber; which } \\
\text { is produced as a waste } \\
\text { product in sugar } \\
\text { production process, was } \\
\text { used as the fiber. }\end{array}$} & $\begin{array}{l}\text { Styrene Acrylic } \\
\text { binder was used as } \\
\text { the chemical } \\
\text { additive. }\end{array}$ \\
\hline \multicolumn{5}{|c|}{ TABLE II: MIX DESIGN } \\
\hline \multirow[b]{2}{*}{ Mixture } & \multicolumn{4}{|c|}{ Ingredients } \\
\hline & DWTS & Sand & Fiber & $\begin{array}{l}\text { Chemical } \\
\text { Additive }\end{array}$ \\
\hline Mix 1 & $\mathrm{x}$ & $\mathrm{O}$ & $\mathrm{O}$ & $\mathrm{O}$ \\
\hline Mix 2 & $\mathrm{x}$ & $\mathrm{x}$ & $\mathrm{O}$ & $\mathrm{O}$ \\
\hline Mix 3 & $\mathrm{x}$ & $\mathrm{O}$ & $\mathrm{x}$ & $\mathrm{O}$ \\
\hline Mix 4 & $\mathrm{x}$ & $\mathrm{x}$ & $\mathrm{x}$ & $\mathrm{O}$ \\
\hline Mix 5 & $\mathrm{x}$ & $\mathrm{O}$ & $\mathrm{O}$ & $\mathrm{x}$ \\
\hline Mix 6 & $\mathrm{x}$ & $\mathrm{X}$ & $\mathrm{O}$ & $\mathrm{x}$ \\
\hline Mix 7 & $\mathrm{x}$ & $\mathrm{O}$ & $\mathrm{X}$ & $\mathrm{x}$ \\
\hline Mix 8 & $\mathrm{x}$ & $\mathrm{x}$ & $\mathrm{X}$ & $\mathrm{x}$ \\
\hline
\end{tabular}

$\mathrm{X}$ - Added in the mix , $\mathrm{O}$ - Not added in the mix

\section{Volumetric Shrinkage Test}

Volumetric shrinkage was measured considering the difference of initial volume and volume after drying as in Fig. 2. Three replicates from each mixture were casted in $70 \times 70 \times 70 \mathrm{~mm}^{3}$ moulds and unmolded after 7 days and let to dry. Three dimensional measurements were taken weekly until 35 days; where volume was constant after completely dry, as shown in Fig. 3. Volumetric shrinkage of each mixture was calculated according to (1); where $S_{v}$ is volumetric shrinkage, $V_{l}$ is initial volume $\left(70^{3} \mathrm{~mm}^{3}\right)$ and $V_{2}$ is final volume at the measuring date [16]. Average of the shrinkage values of three replicates were calculated as the volumetric shrinkage of each mixture.

$$
S v(\%)=\frac{V 1-V 2}{V 1}
$$

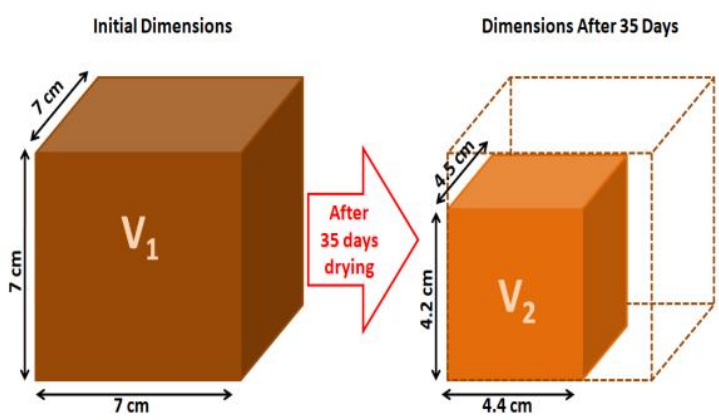

Fig. 2. Volumetric shrinkage.

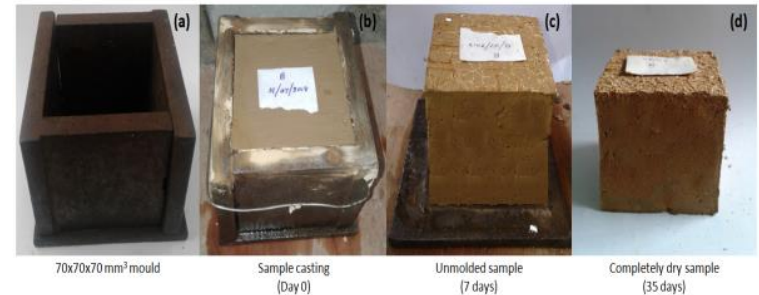

Fig. 3. Volumetric shrinkage test.

TABLE III: CHEMICAL COMPOSITION OF DWTS

\begin{tabular}{ccccccccc}
\hline \hline Element & $\mathrm{Al}$ & $\mathrm{Si}$ & $\mathrm{S}$ & $\mathrm{K}$ & $\mathrm{Ca}$ & $\mathrm{Ti}$ & $\mathrm{Mn}$ & $\mathrm{Fe}$ \\
\hline Mass \% & 24.43 & 42.23 & 0.44 & 2.35 & 5.34 & 1.48 & 0.25 & 23.47 \\
\hline \hline
\end{tabular}

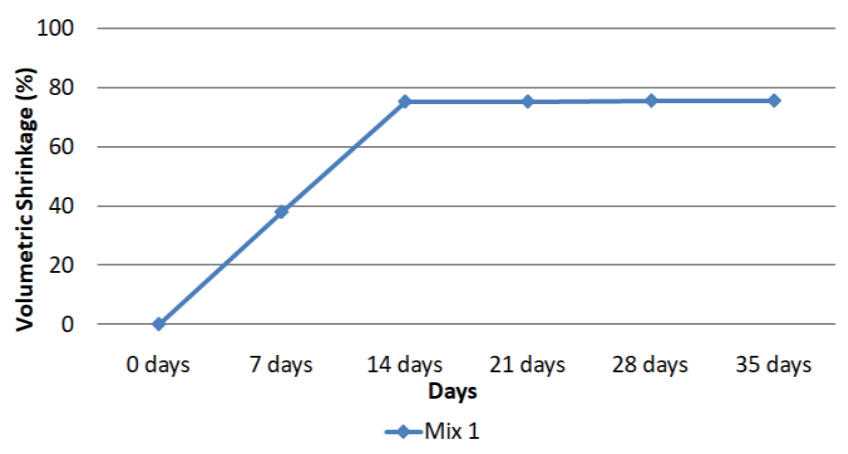

Fig. 4. Volumetric shrinkage variation of DWTS.

\section{RESULTS}

\section{A. Chemical and Physical Properties of DWTS}

As an initial step of the study chemical and physical properties of DWTS were tested. According to the XRF test results chemical composition was determined (see Table III). According to the test results, $\mathrm{Si}(42.23 \%)$ is the highly available chemical element in DWTS and Mn $(0.25 \%)$ is the least available chemical element in DWTS.

Moisture content and particle size distribution of DWTS were also measured. Moisture content of DWTS was measured as $68.38 \%$ in weight basis. According to the wet sieve analysis test results DWTS consist with $4.63 \%$ of sand particles $(D>75 \mu \mathrm{m})$ and $95.37 \%$ of clay particles $(D<75$ $\mu \mathrm{m})$. Volumetric shrinkage of DWTS also initially measured and the results are shown in Fig. 4.

\section{B. Volumetric Shrinkage Test}

Three dimensions of each sample were measured weekly and volumetric shrinkage of each mixture was calculated weekly. Volumetric shrinkage test results are shown in Fig. 5.

According to (a) in Fig. 5, shrinkage values of mixtures prepared by mixing chemical and physical additives has lower shrinkage values compared with the shrinkage value of Mix1. As the results shown in (b) in Fig. 5, Mix 2 and Mix 3 show lower shrinkage values when compared with Mix 1. But the lowest shrinkage was resulted by Mix 4; the mixture with both sand and fiber.

According to (c) in Fig. 5, shrinkage value of Mix 5 was lower than Mix 1. As the results shown in (d) in Fig. 5, Mix 6 and Mix 7 show lower shrinkage values when compared with Mix 1; and Mix 8 show the lowest shrinkage value. But refer to (a) in Fig. 1, Mix 4 has the lowest shrinkage value. 


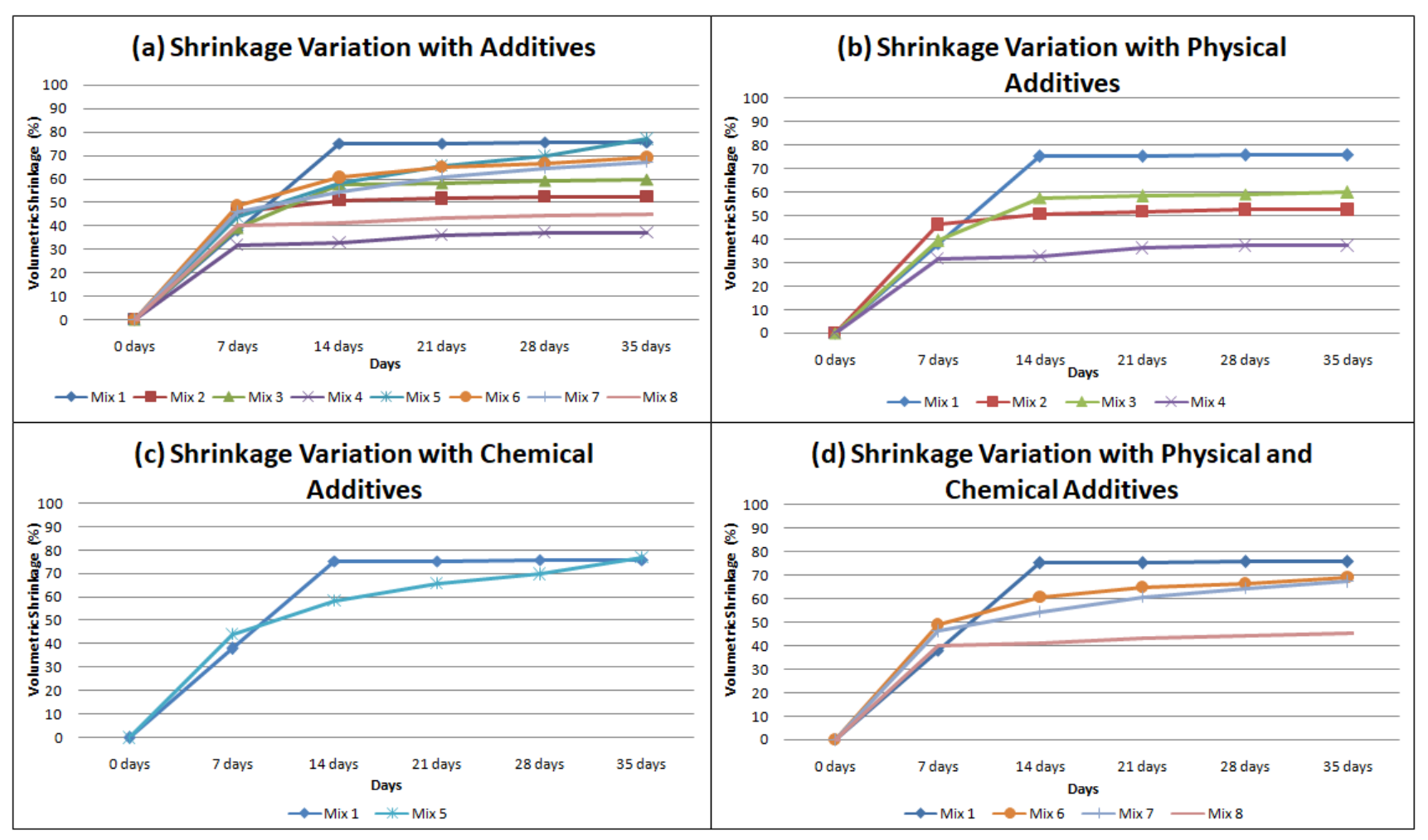

Fig. 5. Volumetric shrinkage variation.

\section{CONCLUSION}

According to the test results volumetric shrinkage of DWTS can be reduced by adding additives; both chemical and physical. Addition of physical additives is the most effective in the reduction of shrinkage when compared with addition of chemical additives to DWTS. Addition of both sand and fiber together result the highest volumetric shrinkage reduction.

As this study is concluded that the volumetric shrinkage of DWTS can be reduced effectively by adding physical additives; the shrinkage issue of DWTS can be successfully overcome. Therefore further studies should be conducted to determine the optimum mixing ratios of the sand and fiber with DWTS to optimize the performances to overcome the volumetric shrinkage and to utilize as a raw material in a production process.

\section{CONFLICT OF INTEREST}

The authors declare no conflict of interest.

\section{AUTHOR CONTRIBUTIONS}

Himahansi and Prof. Rangika conducted the research; Himahansi collected materials, conducted the lab experiments and recorded results under the supervision of Prof. Rangika. Himahansi and Prof. Rangika analyzed the data and wrote the paper and all authors had approved the final version.

\section{ACKNOWLEDGMENT}

Authors would like to acknowledge the National Water Supply and Drainage Board of Sri Lanka (Mr. Dhammika Ranasinghe of R\&D section) for the supply of materials and required data for the study. Supports provided by Mrs. W.B.U. Rukma, Technical Officer of Construction Management division of University of Moratuwa and the staff of the construction material testing laboratory of Department of Civil Engineering, University of Moratuwa in this study are highly appreciated.

\section{REFERENCES}

[1] B. C. O. Kelly, "Geotechnical properties of a municipal water treatment sludge incorporating a coagulant," Can. Geotech. J., vol. 45, pp. 715-725, 2008.

[2] S. Carvalho, J. L. Zhou, W. Li, and G. Long, "Progress in manufacture and properties of construction materials incorporating water treatment sludge : A review," Resour. Conserv. Recycl., vol. 145, pp. 148-159, 2019.

[3] A. Benlalla, M. Elmoussaouiti, M. Dahhou, and M. Assafi, "Utilization of water treatment plant sludge in structural ceramics bricks," Applyed Clay Sci., vol. 118, pp. 171-177, 2015.

[4] Ministry of Water Supply and Drainage, "National drinking water policy," Sri Lanka, 2012.

[5] G. R. Xu, J. L. Zou, and G. B. Li, "Ceramsite obtained from water and wastewater sludge and its characteristics affected by $(\mathrm{Fe} 2 \mathrm{O} 3+\mathrm{CaO}+\mathrm{MgO}) /(\mathrm{SiO} 2+\mathrm{Al} 2 \mathrm{O} 3)$, , Water Res., vol. 43, no. 11, pp. 2885-2893, 2009.

[6] S. R. Teixeira, G. T. A. Santos, A. E. Souza, P. Alessio, S. A. Souza, and N. R. Souza, "The effect of incorporation of a Brazilian water treatment plant sludge on the properties of ceramic materials," Appl. Clay Sci., vol. 53, no. 4, pp. 561-565, 2011.

[7] B. M. C. Wang, J. Q. Hull, M. Jao, B. A. Dempsey, and D. A. Cornwell, "Engineering behavior of w a t e r treatment sludge," J. Environ. Eng., vol. 118, pp. 848-864, 1992.

[8] K. Anjithan, "Management practices of water treatment sludge in $\mathrm{Sr}$ Lanka," University of Moratuwa, 2015.

[9] National Water Supply and Drainage Board, "Sludge Management Policy for Water Treatment Plants," Sri Lanka, 2012.

[10] K. Mahbub, K. Fukushi, K. Turikuzzaman, and S. M. Moniruzzaman, "Effects of using arsenic - iron sludge wastes in brick making," Waste Manag., vol. 34, no. 6, pp. 1072-1078, 2014.

[11] S. Horpibulsuk, C. Suksiripattanapong, W. Samingthong, R. Rachan, and A. Arulrajah, "Durability against Wetting - Drying Cycles of Water Treatment Sludge - Fly Ash Geopolymer and Water Treatment 
Sludge - Cement and Silty Clay - Cement Systems," J. Mater. Civ. Eng., pp. 1-9, 2015.

[12] A. Sales, F. Rodrigues, D. Souza, and C. Rosa, "Mechanical properties of concrete produced with a composite of water treatment sludge and sawdust," Constr. Build. Mater., vol. 25, no. 6, pp. 2793-2798, 2011.

[13] M. Alqam, A. Jamrah, and H. Daghlas, "Utilization of cement incorporated with water treatment sludge," Jordan J. Civ. Eng., vol. 5 , no. 2, pp. 268-277, 2011

[14] C. Huang, J. R. Pan, and Y. Liu, "Mixing water treatment residual with excavation waste soil in brick and artificial aggregate making," $J$. Environ. Eng., vol. 131, no. February, pp. 272-277, 2005.

[15] E. M. Silva, D. M. Morita, A. C. M. Lima, and L. G. Teixeira, "Manufacturing ceramic bricks with polyaluminum chloride ( PAC ) sludge from a water treatment plant," Water Sci. Technol., vol. 71, no. 11, pp. 1638-1645, 2015.

[16] M. Emiroğlu, A. Yalama, and Y. Erdoğdu, "Performance of ready-mixed clay plasters produced with different clay/sand ratios," Appl. Clay Sci., vol. 115, pp. 221-229, 2015.

[17] D. B. Dhanapala, "A short note on the Technique of the Sigiriya Pictures," 2015.

[18] A. S. A. Rashid, N. Latifi, C. L. Meehan, and K. N. Manahiloh, "Sustainable improvement of tropical residual soil using an environmentally friendly additive," Geotech. Geol. Eng., vol. 35, no. 6, pp. 2613-2623, 2017.

[19] M. Singh, S. V. Kumar, and S. Waghmare, "Mud plaster wall paintings of bhaja caves: Composition and performance characteristics," Indian J. Hist. Sci., vol. 51, no. 3, pp. 431-442, 2016.

[20] J. R. Rosell, L. Haurie, A. Navarro, and I. R. Cantalapiedra, "Influence of the traditional slaking process on the lime putty characteristics," Constr. Build. Mater., vol. 55, pp. 423-430, 2014.

[21] S. T. Methods, "Standard test methods for physical testing of quicklime, hydrated lime, and," vol. i, pp. 1-24, 2016.

[22] S. H.Kosmatka, M. L.wilson, and W. C. Panarese, "Admixtures for Concrete," Design and Control of Concrete Mixtures, 14th Editi., USA Portland Cement Association, 2011, pp. 105-119.

[23] C. Udawattha, D. E. Silva, H. Galkanda, and R. Halwatura, "Performance of natural polymers for Stabilizing earth blocks," Materialia, vol. 2, no. August, pp. 23-32, 2018.

Copyright $\odot 2020$ by the authors. This is an open access article distributed under the Creative Commons Attribution License which permits unrestricted use, distribution, and reproduction in any medium, provided the original work is properly cited (CC BY 4.0).

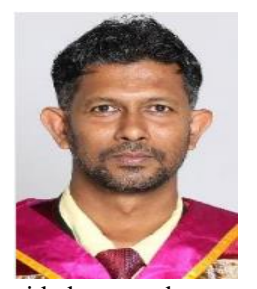

Rangika U. Halwatura graduated with a B.Sc. in civil engineering from University of Moratuwa, Sri Lanka in 2004 and attained Ph.D. in structural and building services engineering from University of Moratuwa, Sri Lanka in 2008. His major fields of study are sustainable material and design, green technology, construction management, structural designing, project planning and monitoring, computer aided server base project planning and monitoring, forensic engineering, BIM (building information modeling).

$\mathrm{He}$ is currently working as a professor in the Department of Civil Engineering, University of Moratuwa, Sri Lanka. He is a chartered engineer in Institution of Engineers, Sri Lanka (IESL), and Commissioner in Sri Lanka Inventors Commission (SLIC); in addition he has professional memberships in many technical bodies like NEC, NHRDC, SLAAS and GBCSL. He has more than 15 years of teaching experience and has around 100 of publications in national and international journals, conferences, books and book chapters; and few of the most reason publications are listed below,

- F.R. Arooz, R.U. Halwatura, Mud-concrete block (MCB): mix design \& durability characteristics, Case Studies in Construction Materials, Volume 8, June 2018, Pages 39-50

- R.U. Galagoda , G.Y. Jayasinghea, R.U. Halwatura , H.T. Rupasinghe, The impact of urban green infrastructure as a sustainable approach towards tropical micro-climatic changes and human thermal comfort, Urban Forestry \& Urban Greening, 2018

- S Pathirana,- A Rodrigo,- R U Halwatura,Effect of building shape orientation, window to wall ratios and zones on energy efficiency and thermal comfort of naturally ventilated houses in tropical climate, International Journal of Energy and Environmental Engineering, 2018.

Prof. Halwatura is guiding about 7 fellows for the Ph.D program while working as a Professor in Department of Civil Engineering, University of Moratuwa, Sri Lanka. He has visited many foreign countries for presenting research papers in international conferences. He has also delivered many invited talks and also chaired and co-chaired national and international conferences and also a reviewer of several international journals. He was awarded in several times for his contribution to the development of science and technology; the most reason few awards are listed below,

- TWAS ( The World Academy of Science) Young scientist award - 2017

- Award for Outstanding Research award with distinction, University of Moratuwa. 2017

- Presidential Awards for Academic Publications, 2018 